See discussions, stats, and author profiles for this publication at: https://www.researchgate.net/publication/322328663

\title{
What are the Effects of Large-scale Violence on Social and Institutional Trust? Using the Civil War Literature to Understand the Case of Mexico, 2006-2012
}

Article in Civil Wars · January 2018

DOI: 10.1080/13698249.2018.1446112

CITATIONS

READS

0

213

5 authors, including:

John Ishiyama

University of North Texas

194 PUBLICATIONS 2,557 CITATIONS

SEE PROFILE

Felipe Carlos Betancourt Higareda

Universidad Autónoma del Estado de México (UAEM)

9 PUBLICATIONS 1 CITATION

SEE PROFILE

Amalia Pulido

University of North Texas

7 PUBLICATIONS 9 CITATIONS

SEE PROFILE

Some of the authors of this publication are also working on these related projects:

communist and post communist studies View project

Project International Interactions View project 
What are the Effects of Large-Scale Violence on Social and Institutional Trust? Using the Civil War literature to understand the case of Mexico, 2006-2012

\author{
John Ishiyama \\ University of North Texas \\ Felipe Carlos Betancourt Higareda, \\ Universidad Autónoma del Estado de México \\ Amalia Pulido, \\ University of North Texas \\ Bernardo Almaraz, \\ Centro de Investigación y Docencia Económicas A.C
}

Paper accepted and forthcoming in Civil Wars

Corresponding Author: John Ishiyama (john.ishivama@unt.edu)

Address: Department of Political Science

1155 Union Circle \#305340

Denton, TX 76203-5017 
There has been an increasing interest in the past few years in using the literature on civil wars to understand the large-scale drug violence that has occurred in Mexico. Up until recently, however, rigid disciplinary boundaries have worked against integrating the study of organized crime violence and political violence. As Kalyvas $(2015,1518)$ notes "crime has been a topic of choice for sociologists, while political scientists have focused primarily on political violence". Nonetheless, the unprecedented scale of drug violence in Mexico have caused many to turn to the civil war literature to help understand conflict in Mexico (Kalyvas 2015; Osorio 2013; Schedler 2013;). Some, like Schedler, suggest that the large-scale drug violence in Mexico is in effect a "civil war" (see also Bergal, 2011). Based in part on the earlier work of Collier and Hoeffler (2004) that suggested rebel groups are motivated largely by greed, he argues that "In terms of motivation, the driving motives of violence [in Mexico] are not ideology, but material gain. The new Mexican civil war is not a classical civil war in which ideological insurgencies strive to topple state power. It is a prototypical 'new' civil war, fought for material gain not social justice" Schedler $(2013,6)$.

Kalyvas (2015), however, is critical of attempts to characterize the large-scale drug violence in Mexico as a civil war, largely because the drug cartels do not have a political objective designed to undermine the existing political status quo, either via state capture or secession. Although dismissing the "civil war as organized crime" approach, he suggests that the existing civil war literature can be usefully employed to understand micro dynamics of large scale drug conflict, namely, the: 1) onset and termination of large-scale drug conflict; 2) organization of drug cartels; 3) the escalation of violence; and 4) how Drug Trafficking Organizations (DTOs) govern territory. 
A fifth area where the civil war literature may be applicable to large-scale drug violence, relates to the political consequences of civil wars (Ishiyama 2014; Garcia-Ponce and Pasquale 2013). Recently, scholars have begun to examine the consequences of civil wars on post war politics, particularly how civil violence shapes political attitudes. For instance, Bellows and Miguel (2006, 2009), Blattman (2009), Cassar et al. (2013) and Voors and Bulte (2014) have all examined the how conflict affects social capital, particularly attitudes about political institutions and cooperative behavior (and interpersonal trust). Some argue that conflict increases trust, leading to greater participation in community organizations and political (Blattman, 2009; Bellows and Miguel, 2006, 2009). However, others contend that exposure to civil conflict reduces interpersonal trust, as well as trust in political institutions (Voors and Bulte, 2014; Cassar et al., 2013; Colletta and Cullen 2000).

This represents our point of departure for this article--what is the relationship between large scale drug violence and political attitudes in Mexico? Although there have been many recent works that have examined the political consequences of drug violence in Mexico, most of these have focused on the impact of violence on the prospects for Mexico emerging as a "failed state" (Michaud 2011; Grayson 2011; O’Neil 2009) or has analyzed the impact from the perspective of criminological studies (see Rios and Shirk 2011). In general, there have been remarkably few works (at least in English) that have examined the social and political consequences of drug related violence in Mexico. ${ }^{1}$ The research that has focused on the relationship between politics and violence has generally concentrated on how the introduction of political competition as an independent variable affected the level of violence as a dependent variable (see Osorio 2012; Escalante 2011; O’Neil 2009; Astorga 2005). 
More recently, some studies have examined how drug violence has directly affected politics in the country. Ley (2017), argues that criminal violence influences electoral participation, voting behavior and non-electoral participation. She shows that victims of crime in Mexico are less likely to vote, and the incumbent party is less likely to receive electoral support. On the other hand, she finds that, while criminal violence may have a negative effect on turnout, it increases non-electoral participation. Rey (2015) also shows that widespread violence depressed voter turnout in recent elections, which thus affected electoral outcomes in Mexico (generally affecting PAN supporters more than supporters of other parties). Schedler (2014) argues that the widespread violence in Mexico directly serves to undermine Mexican democracy, by threatening electoral integrity and eroding confidence in Mexican political institutions. Blanco (2013) suggests violence has decreased voters' confidence in democracy in Mexico, with marked decreases in trust in judicial and legal institutions as the result of violence.

However, what is generally lacking in much of this literature is on how violence has affected political attitudes in Mexico, in particular social and institutional trust (with the partial exception of Blanco, 2013). Further, we contend that not enough attention has been paid in the literature to separating out the individual and contextual (or sociotropic) effects of violence on individual attitudes. In this paper we examine the impact of individual experiences with criminal violence, perceptions of security in one's neighborhood, and higher levels of drug related violence at the community (municipio) level (proxied by drug related homicides) have on two important elements of democracy- social (or interpersonal trust) and institutional trust. Using geo referenced data from the Latin American Public Opinion Project (LAPOP) and municipality (municipio) level data regarding levels of violence, as well as other control variables, we test 
these relationships using data from a sample of 110 of the 2456 municipios in Mexico from 2006-2012.

\section{Literature}

The idea that social trust is crucial for the development of democracy has long been a central theme in the literature on political culture (Almond and Verba 1963). In particular, social trust is seen as necessary for the emergence of civil society, which is widely believed to be essential for the development of political democracy (Foley and Edwards 1996, 38). It is often argued that social trust directly supports democracy in that people trusting one another leads to the formation of secondary associations, "which, in turn, support the stability of democratic rule" (Mackie 2001, 246).

A second type of trust that is considered important to the development of political stability and democracy is institutional trust or confidence in existing political institutions. David Easton (1965) argued that in order for a political system to function it needs legitimacy through the public support of the system's institutions as well as the system as a whole. Indeed, a requirement for the stability of democracy is that the public is generally supportive of the regime and confident in its institutions (Chanley, Rudolph and Rahn, 2000; Newton and Norris, 2000). Further, trust in institutions is related to the promotion of social trust because trust in institutions and the "the ability of associational life in general and the habits of association in particular foster patterns of civility in the actions of citizens" (Foley and Edwards 1996, 39). Institutional trust is thus an essential part of the development of civility and, hence, the development of democracy.

\section{Violence and Trust}


So how does large-scale violence affect social and institutional trust? There has been a considerable amount of literature, particularly in sociology, that examines the relationship between violence and social capital. Although much of this literature has historically focused on how social trust impacts the likelihood of political violence (Bohara, Mitchell and Nepal 2006; Benson and Rochon 2004; Dahlberg and Potter 2001; Lederman Loayza and Menendez 2002; Robison and Siles 1999; Brehm and Rahn 1997; Glaeser and Sacerdote 1996; Fukuyama 1995), others have examined the effects of violence on social trust and social capital (Colletta and Cullen 2000; Cassar et al., 2013; Voors and Bulte, 2014).

There has been considerable debate in the literature on whether violence leads to less social trust. Caroline Moser and Jeremy Holland (1997) and Moser and Elizabeth Shrader (1998) argue that violence in Latin America and the Caribbean countries has eroded social capital in diverse ways. Violence prevents communities from meeting locally, prevents individuals (especially women) from going to work and therefore extending their social network, increases school drop-out rates, and impairs the coverage of health services. These authors find that "there are often higher levels of participation in community action groups in less violent areas, and lower in more violent areas" (Moser and Schrader, 1998, p. 9). Colletta and Cullen (2000, 3-4) also argue that civil violence reduces trust. They note that violent conflict reduces interpersonal trust and social capital and contend that that "unlike interstate conflict, which often mobilizes national unity and strengthens social cohesiveness, violent conflict within a state weakens its social fabric. It divides the population by undermining interpersonal and communal trust, destroying the norms and values that underlie cooperation and collective action for the common good, and increasing the likelihood of communal strife". 
More recently Kijewski and Freitag (2016), in their study of post war Kosovo, also argue that civil war negatively affects social trust - however they acknowledge that individual level experiences with violence are more directly related to social trust, more so than the effects of proximity to conflict. Nonetheless, they contend that civil wars have "lasting psychological as well as social structural consequences provides people with clear evidence of the untrustworthiness, uncooperativeness, and hostility of others diminishing social trust in the aftermath of war" (Kijewski and Freitag 2016, p. 1)

Conversely, there are also reasons to think that violence may lead to more social trust. In certain contexts, stronger social interactions allow individuals involved in criminal activities to exchange information and knowhow that diminish the costs of crime more easily. Furthermore, deep ties among community members may facilitate the influence of "successful" criminals, enacting them as role models and inducing stronger tastes and propensity for crime and violence in the community. According to Glaeser, Sacerdote, and Scheinkman (1999), these perverse social interactions may be the fundamental cause of the observed inertia of crime rates in cities in the United States. Mauricio Rubio (1997) analyzes the role of drug cartels, guerrilla groups, and gangs in generating a perverse social capital in Colombia. He argues that these groups corrupt whole communities by providing youths with role models and by training them in the use of arms and violence.

More recently, several scholars have suggested that civil wars can have positive effects on individual attitudes and behavior. Thus, Bellows and Miguel (2006; 2009), Blattman (2009) and Gilligan, Pasquale, and Samii (2013) have demonstrated how civil wars create the post war conditions for increased collective action, prosocial behavior, and political participation, Bellows and Miguel (2009) in particular find that civil war victimization does not affect trust within 
communities, and led to higher levels of trust with individuals outside of the local community. These studies have suggested that the positive effects of civil war on social trust are due to what psychologists refer to as post-traumatic growth (PTG) (Calhoun and Tedeschi 2006; Tedeschi and Calhoun 1996). This approach argues that trauma resulting from violence can lead to personal growth, such as inducing new ways to relate with others. Indeed, research on PTG has found that individuals often feel more compassionate toward others as a response to violent trauma. (Glaeser et al. 2000).

Some have argued that there is no relationship between violence and social trust (Dineson et al 2013). For instance, Geys and Qari (2017) suggest that exposure to political violence has only very short-term effect and that there are no long-term effects of violence on generalized social trust. They suggest that violent events have only very limited, transitory effects on established social attitudes. Similarly, Arvanitdis, Economou and Kollias (2016), using data from the European Social Surveys, also find that the effects of violent events (such as terrorism) have no long-term effects on social trust, even in countries that have experienced multiple terrorist events. They suggest that in response to violence, individuals compartmentalize such events, and think of these events as "external" to themselves. However, these studies focused largely on the socio tropic or contextual effects of terrorist attacks on social trust, as opposed to the individual experiences of respondents.

There has also been some literature that has examined the effect of violence on attitudes vis-à-vis confidence in judicial institutions and political institutions. Hoglund (2008) suggests that excessive levels of political and criminal violence will severely challenge the legitimacy of the governing institutions. Hoglund further points out that that disproportionate levels of crime undermine people's trust in the state institutions and democracy. Other scholars suggest that civil 
wars also reduce political trust. For instance, De Juan and Pierskalla (2016), in their study of Nepalese villages after the end of the civil war in that country, argue that exposure to civil war significantly reduces political trust in national governmental institutions. This is because the violence undermined confidence in governmental institutions to provide basic services and security to the population.

There has also been some work on the impact of large-scale violence in Mexico on institutional trust. Blanco $(2011 ; 2013)$ using cross sectional individual data from the Latin American Public Opinion Project and ENSI shows that (using the case of Mexico) perceptions of higher insecurity at the individual level decreases support and satisfaction with democracy. Further they find that violence and the perceptions of insecurity reduce trust in institutions, particularly in those that directly deal with crime (police and judicial system). However, this paper does not examine the nested effects of general regional levels of crime on trust in institutions (or the sociotropic effect of perceptions of crime) and the paper does not examine the impact of drug violence on social or interpersonal trust. Nonetheless this paper is one of the few that have sought to examine the impact of the rise of drug violence on levels of trust.

However, some recent work by Garcia-Ponce and Pasquale (2013), using data from Africa (Afrobarometer) suggests that political violence in fact helps promote more positive assessments of the government. They find that individuals interviewed shortly following the occurrence of violent events in their district are substantially more likely to report trust in their head of state, parliament, local government officials, and police forces. The authors suggest that this allows leaders to pursue strategies against the opposition (and promoting violence) in order to produce more support for the incumbent regime. 
In sum the literature has been rather divided regarding the impact of violence on social and political trust. Part of this may be due to the different levels of analysis. Many scholars who have examined individual experiences with violence conclude that such experiences reduce social and institutional trust. However, others who have examined the socio tropic or contextual effects of violence on the attitudes of those who live in proximity to large-scale violence find less support for the thesis that violence reduces social and political trust. For example Dineson et al (2013) suggest that violence has no effect on social trust, particularly at the group level but may have an effect on reducing trust at the individual level(or what they refer to as the difference between "structural social capital" and "cognitive social capital"). This suggests that to understand the effects of large-scale drug violence on social and political trust in Mexico requires disaggregating both individual and contextual level effects of violence.

For our purposes, there are three levels to take into account in examining the relationship between violence and individual attitudes - individual experience, neighborhood effects, and regional/municipio effects. In the first, individual experiences with violence and crime should impact the level of social trust, although as we noted above there is some debate over the direction of that effect. The second is the neighborhood effect, or where violence is perceived to occur within close proximity to the individual and represents a threat to the individual, but the individual has not experienced violence personally. The third is the regional context, in which the individual is aware of violence in the region in which they live, and the effects, if any, are largely sociotropic. Awareness of violence affects the individual, but only because of greater fear that violence is rising generally.

Before we turn to the quantitative analysis it is first necessary to provide a brief background to the large-scale violence that dramatically increased in the period 2006-2012. 


\section{Drug Violence in Mexico 2006-2012}

The history of rising violence associated with Drug Trafficking Organizations (DTOs) is well known among students of Mexican politics. Shortly after assuming office on December 1, 2006 President Felipe Calderon launched a war on the Mexican Drug Trafficking Organizations (DTOs) when 6500 troops were deployed to the state of Michoacan to end the violence between DTOs there. Although violence between drug cartels had been occurring for three decades, to that point the Mexican state had generally adopted a very passive stance vis a vis the cartels through the 1980s and early 2000s, with the former governing Institutional Revolutionary Party (Partido Revolucionario Institucional, PRI) establishing a tacit agreement with the drug lords (e.g. Astorga 2005). Indeed, the system that the PRI created quelled political violence by incorporating the opposition and paying of important private sector supporters (Rodríguez and Ward 1994). These ties included ties with criminal elements as well. Ties between the PRI and illegal traders began in the 1920s and 1930s and had solidified by the end of World War II (Michaud, 2011; Klessner and Lawson 2004). In particular patron-client relationships between local officials and drug traffickers maintain the peace. In exchange for limiting violence against officials and civilians, the authorities made sure that there would be no prosecution of top drug traffickers (see also Rios and Shirk 2011, p. 16).

This changed dramatically in 2006. The deployment of troops in Michoacan was widely regarded as the starting point of the Mexican government's war against the cartels. As time passed, Calderón continued to escalate his anti-drug campaign so that by 2012 45,000 troops and police forces were involved in the war against the cartels.

The escalation of the drug war resulted in a dramatic increase in violence, reflected in rising homicide, and cartel related homicides between 2007-2012. While homicides were 
declined till the mid-2000s, they grew dramatically after 2007. According to Molzan, Rodriguez and Shirk (2013, p. 15) drug related killing increased dramatically from 2007-2012. Under Presidents Ernesto Zedillo (1994-2000) and Vicente Fox (2000-2006), the number of homicides declined, but under President Calderón (2006-2012), homicide levels increased to unprecedented levels. For instance, the general homicide rate increased from about 10,000 homicides in 2006 nationwide, to approximately 27,000 homicides in 2011 . This increase was largely "attributable to drug trafficking and organized crime groups" (Molzan, Rodriguez, Shirk 2013, p. 3). Schedler reports that the number of homicides attribtued to organized crime in Mexico increased fom 2,221 in 2006 to 16,603 in 2011, a nearly $750 \%$ increase.

Further, there was a shift in the geographic distribution of drug related violence between 2006 and 2011. As Molzan, Rodriguez and Shirk (2013 p. 20) note, the "the most obvious pattern illustrated by these data is the geographic proliferation of homicides over the course of the last several years". As they note, in 2007 there were 1,876 municipalities with no reported homicides. However, by 2011 this number had decrease by $28 \%$ to 1,337 . At the same time the number of municipalities that had experienced 25 or more annual homicides increased by almost a factor of five from 50 in 2007 to 240 in 2011.

Thus, between 2006-2011 there was a dramatic increase in the level of drug related violence throughout the country. What were the effects of such violence on the level of interpersonal/social trust and institutional confidence? In the next section we outline the basic features of our research design, which seeks to address these questions.

\section{Hypotheses}

Based on the above literature we can derive several hypotheses related to the effects of violence on social trust/interpersonal trust and trust in political institutions. Further, as suggested 
by the literature we examine each of these in terms of both individual, neighborhood, and municipio level effects.

- Hypothesis 1: In municipios and neigborhoods where there are higher levels of DTO related violence (and for individuals experiencing violence) there will be lower levels of social trust

- Hypothesis 1a: In municipios where DTO related violence has increased, there will be lower levels of social trust

- Hypothesis 2: In municipios and neigborhoods where there are higher levels of DTO related violence (and for individuals experiencing violence) there will be lower levels of trust in a) judicial institutions b) the legislature c) local government

- Hypothesis 2a: In municipios where DTO related violence has increased, there will be lower levels of trust in political institutions

However, as indicated by the above literature, there is great potential endogeneity problem when examining the relationship between violence and especially social trust/interpersonal trust. It is very likely that they affect each other. In order to address this issue, we conduct a further analysis of a sample of municipios, first establishing that in terms of trust, there was no significant difference between subsequently high violence municipios versus low violence municipios and then comparing, in a quasi-experimental way, the effects of the rise in 
violence between 2007-2011 on levels of social and institutional trust. We would expect that if violence has a negative effect on trust, the decline in trust should be most pronounced in municipios that experience high levels of violence. For this hypothesis we only examine municipio level effects.

This suggests the following hypothesis:

- Hypothesis 3: In municipios where there were high levels of DTO related violence there were be a more pronounced decrease in social trust and trust in institutions than in municipios that did not experience high levels of violence.

\section{Methodology}

To test the above hypotheses we collected individual level data from a sample of 110 municipios in Mexico (from the LAPOP survey data for 2012), which included 1557 respondents. The 110 municipios were randomly selected from the total of 2456 municipios, and then survey respondents were randomly selected within each municipio. Thus, we are confident that that the sample is representative of the Mexican population. Table 1 lists the municipios employed for the purposes of this study

\begin{tabular}{|l|l|l|}
\hline \multicolumn{3}{|c|}{ Table 1: List of Municipios included in the 2012 LAPOP wave } \\
\hline Region & State & Municipality \\
\hline West & Aguascalientes & Tepezalá \\
\hline Northwest & Baja California & Mexicali \\
\hline Northwest & Baja California & Tijuana \\
\hline Northwest & Baja California & Comodú \\
\hline Northwest & Baja California Sur & Los Cabos \\
\hline Southeast & Campeche & Hopelchen \\
\hline Northeast & Coahuila & Parras \\
\hline Northeast & Coahuila & Saltillo \\
\hline Northeast & Coahuila & San Juan de Sabinas \\
\hline West & Colima & Villa de Álvarez \\
\hline
\end{tabular}




\begin{tabular}{|l|l|l|}
\hline Southeast & Chiapas & Amatan \\
\hline Southeast & Chiapas & Bochil \\
\hline Southeast & Chiapas & Tuxtla Gutiérrez \\
\hline Southeast & Chiapas & Villa Corzo \\
\hline Northwest & Chihuahua & Ahumada \\
\hline Northwest & Chihuahua & Chihuahua \\
\hline Northwest & Chihuahua & Juárez \\
\hline Northwest & Chihuahua & Ojinaga \\
\hline Center & Distrito Federal & Gustavo A. Madero \\
\hline Center & Distrito Federal & Iztacalco \\
\hline Center & Distrito Federal & Iztapalapa \\
\hline Center & Distrito Federal & Álvaro Obregón \\
\hline Center & Distrito Federal & Tláhuac \\
\hline Center & Distrito Federal & Benito Juárez \\
\hline Center & Distrito Federal & Cuauhtémoc \\
\hline Northeast & Durango & Cuencamé \\
\hline Northeast & Durango & Lerdo \\
\hline Northeast & Durango & Acámbaro \\
\hline West & Guanajuato & Dolores Hidalgo \\
\hline West & Guanajuato & León \\
\hline West & Guanajuato & Moroleón \\
\hline West & Guanajuato & Pénjamo \\
\hline Center & Guerrero & Eduardo Neri \\
\hline Center & Guerrero & Iguala de la Independencia \\
\hline Center & Guerrero & Leonardo Bravo \\
\hline Center & Guerrero & Metlatónoc \\
\hline Center & Hidalgo & Nopala de Villagrán \\
\hline Center & Hidalgo & Pachuca de Soto \\
\hline Center & Hidalgo & San Felipe de Orizatlan \\
\hline Center & Hidalgo & Tepeji del Río de Ocampo \\
\hline West & Jalisco & Atotonilco el Alto \\
\hline West & Jalisco & Zapotlán el Grande \\
\hline West & Jalisco & Jamay \\
\hline West & Jalisco & San Juan De los Lagos \\
\hline West & Jalisco & Tlaquepaque \\
\hline West & Jalisco & Tonalá \\
\hline West & Jalisco & Zapopan \\
\hline Center & México & Atizapán de Zaragoza \\
\hline Center & México & Chicoloapan \\
\hline Center & México & Cuautitlán Izcalli \\
\hline Center & México & Ecatepec de Morelos \\
\hline Center & Ixtapaluca \\
\hline Center & & Netepec \\
\hline Center & \\
\hline & & \\
\hline
\end{tabular}




\begin{tabular}{|l|l|l|}
\hline Center & México & Nezahualcóyotl \\
\hline Center & México & Nicolás Romero \\
\hline Center & México & Tlalnepantla de Baz \\
\hline Center & México & Toluca \\
\hline Center & México & Zumpango \\
\hline Center & México & Valle de Chalco \\
& & Solidaridad \\
\hline West & Michoacán & Morelia \\
\hline West & Michoacán & Pátzcuaro \\
\hline West & Michoacán & Zamora \\
\hline West & Michoacán & Zitácuaro \\
\hline Center & Morelos & Jiutepec \\
\hline West & Nayarit & Ahuacatlan \\
\hline West & Nayarit & Tepic \\
\hline Center & Morelos & Yautepec \\
\hline Northeast & Nuevo León & Monterrey \\
\hline Northeast & Nuevo León & San Nicolás de los Garza \\
\hline Northeast & Nuevo León & Santa Catarina \\
\hline Southeast & Oaxaca & Asunción Ixtaltepec \\
\hline Southeast & Oaxaca & Mesones Hidalgo \\
\hline Southeast & Oaxaca & Oaxaca de Juárez \\
\hline Southeast & Oaxaca & San Lucas Ojitlan \\
\hline Center & Puebla & Caltepec \\
\hline Center & Puebla & Honey \\
\hline Center & Puebla & Huaquechula \\
\hline Center & Puebla & Ocoyucan \\
\hline Center & Puebla & Puebla \\
\hline West & Querétaro & El Marqués \\
\hline West & Querétaro & Querétaro \\
\hline Southeast & Quintana Roo & Othón P. Blanco \\
\hline Northeast & San Luis Potosí & Matehuala \\
\hline Northeast & San Luis Potosí & San Luis Potosí \\
\hline Northeast & San Luis Potosí & Tampamolón Corona \\
\hline Northeast & San Luis Potosí & Villa Juarez \\
\hline Northwest & Tamauloa & Angostura \\
\hline Northwest & Sinaloa & Culiacán \\
\hline Northwest & Sinaloa & Rosario \\
\hline Northwest & Sinaloa & San Luis Rio Colorado \\
\hline Northwest & Sonora & Guaymas \\
\hline Northwest & Sonora & Navojoa \\
\hline Southeast & Centro \\
\hline Southeast & Paraíso \\
\hline Northeast & Reynosa \\
\hline Northeast & \\
\hline & Tabaso & \\
\hline
\end{tabular}




\begin{tabular}{|l|l|l|}
\hline Center & Tlaxcala & Ixtenco \\
\hline Southeast & Veracruz & Boca del Río \\
\hline Southeast & Veracruz & Coatzacoalcos \\
\hline Southeast & Veracruz & Cosoleacaque \\
\hline Southeast & Veracruz & Hueyapan de Ocampo \\
\hline Southeast & Veracruz & Xalapa \\
\hline Southeast & Veracruz & Orizaba \\
\hline Southeast & Veracruz & Papantla \\
\hline Southeast & Veracruz & Playa Vicente \\
\hline Southeast & Veracruz & Uxpanapa \\
\hline Southeast & Yucatán & Mérida \\
\hline West & Zacatecas & Fresnillo \\
\hline West & Zacatecas & Tabasco \\
\hline
\end{tabular}

To measure the dependent variable the level of interpersonal trust (or "social trust") we used the following question

IT1. And speaking of the people from around here, would you say that people in this community are very trustworthy, somewhat trustworthy, not very trustworthy or untrustworthy...?

(1) Very trustworthy (2) Somewhat trustworthy (3) Not very trustworthy

(4) Untrustworthy (88) DK (98) DA

We recoded the question into dummy variable in which the response categories 1 and 2 were recoded as a " 1 " and 3 and 4 were recoded as a " 0 ". This set the higher value as indicating a higher level of social trust.

For the institutional trust dependent variables, we employed the following question. For trust in the judiciary we used:

B10A. To what extent do you trust the justice system?

For trust in the legislature we used:

B13. To what extent do you trust the National Legislature?

And for trust in local government we used: 
B32. To what extent do you trust the local or municipal government?

In each case we recoded the response categories in a way identical to the measure we created for social trust, where the higher value indicated more trust, and the lower value less. Regarding the primary independent variables, we developed measures for individual experience with violence, neighborhood perceived levels of threat of neighborhood violence, and municipio levels of violence. To account for the experiences of individuals with violence, we used the question regarding whether the respondent had reported being a victim of a crime, which includes many activities associated with organized crime such as armed robbery, assault, fraud, blackmail, extortion or violence (VIC1EXT in the LAPOP code book, with $1=$ yes and $2=$ no). Although this does not perfectly match with individual experiences with violence, it is a reasonable proxy for being victims of organized crime activities.

To account for the neighborhood effect we included responses to three questions where the respondent was asked to assess the level of security in his/her neighborhood, and to assess whether or not the primary security threat in the neighborhood came from drug gangs.

Respondents were asked whether they felt safe in their neighborhood (AOJ11), whether they felt safer or less safe than five years ago (AOJ20) and whether they saw drug gangs as the principal threat to their security in the neighborhood (recoded variable derived from AOJ21).

To examine the level of violence by municipio, and increases in the level of violence by municipio, we collected data from INEGI for homicides per municipality (as a proxy for drug related violence) and calculated the number of deaths per 1000 population, per year, and then averaged the number of deaths per year for the period 2007-2011. Second we calculated the percentage change in the number of deaths per population over the period 2007-2011. These were measured at the municipio level.For our control variables, we included both individual 
level measures and municipio level measures. At the individual level we included individual evaluations of the economy, both currently (in 2012) and changes over time (since 2011) and individual evaluations of their own economic circumstances. These questions from LAPOP were:

SOCT1. How would you describe the country's economic situation? Would you say that it is very good, good, neither good nor bad, bad or very bad?

(1) Very good (2) Good (3) Neither good nor bad (fair) (4) Bad

(5) Very bad (88) Doesn't know (98) Doesn't Answer

SOCT2. Do you think that the country's current economic situation is better than, the same as or worse than it was 12 months ago?

(1) Better (2) Same (3) Worse (88) Doesn't know (98) Doesn't Answer

IDIO1. How would you describe your overall economic situation? Would you say that it is very good, good, neither good nor bad, bad or very bad?

(1) Very good (2) Good (3) Neither good nor bad (fair) (4) Bad

(5) Very bad (88) Doesn't know (98) Doesn't Answer

IDIO2. Do you think that your economic situation is better than, the same as, or worse than it was 12 months ago?

(1) Better (2) Same (3) Worse (88) Doesn’t know (98) Doesn’t Answer

We also took into account the respondent's estimated income level, and whether or not the respondent consider themselves "white" (recoded as "1") or other (recoded as 0 which included, mestizo, indigenous, black, mulatto, or of another race)

At the municipio level data were also collected data that measured economic performance by calculating the GDP per capita change over the five year period by municipality for the period 2006-2012. These data was available at INEGI

http://www.inegi.org.mx/est/contenidos/proyectos/ccpv/cpv2010/Default.aspx.

\section{Analysis}

In terms of the method of analysis, since we hypothesize, along with individual level responses, that municipio level characteristics affect individual level attitudes, we are essentially 
arguing that the dependent variable is effectively nested within the independent variable. Thus, we opt for a mixed effects logistic regression model with categorical dependent variables, (e.g moderate/high trust or little/no trust). Multi-level logistic regression is used to model binary outcome variables, where the log odds of the outcomes are modeled as a linear combination of the predictor variables when data are clustered or there are both fixed and random effects. This makes it particularly useful to assess the effects of higher level characteristics (such as the level of violence in municipios) on individual level responses (such as the level of social and institutional trust).

Table 2 report the results of a multilevel logistic regression analysis using clustered robust standard errors with odds ratios reported rather than coefficients. Odds ratios are interpreted differently than general coefficients. When an odds ratio larger than 1 , this indicates the percent increase in the dependent variable; when the odds ratio is below 1, this indicates the percent decrease in the dependent variable. In addition Variance Inflation Factors (VIFs) were calculated for each model, and none of the VIF scores exceeded "2" indicating that there were not issues of multicollinearity that would affect our results.

The results partially support hypothesis 1 above, but not at the individual level. As indicated in table 2, in terms of interpersonal or social trust, individual level experience with crime actually increased the likelihood of higher levels of social trust, by about $9 \%$ (although this relationship is not statistically significant) which runs counter to hypothesis 1 above. Thus, the results neither support those who argue that individual experiences with violence reduces or increases social trust. However, neighborhood and municipio effects are more important in explaining reductions in social trust. The extent to which individuals feel unsafe in their neighborhoods, and less safe than before, are both significantly related to decreases in the 
likelihood of expressing high levels of social trust. Feeling unsafe in the neighborhood reduces social trust by about $31 \%$ and feeling less safe than five years before reduced social trust by about 25\% (which are consistent with they hypotheses above). Further at the municipio level, the higher the average annual homicide rate per 1000 population the lower the level of social trust of the individual residing in that municipality (although the magnitude of that effect is quite small, with a reduction in social trust of only $.07 \%$ ). Changes in the annual homicide rate over time is unrelated to social trust (contrary to hypothesis 1a).

However, lessened social trust may not necessarily be linked to the activities of drug related gangs. Indeed, whether the respondent identified drug gangs as the principal threat in their neighborhood was unrelated to the level of social trust, and increases in violence at the municipio level was unrelated to levels of social trust. This suggests that what negatively affects social trust is a general sense of insecurity for individuals brought on by the sociotropic perception of higher levels of violence generally, unrelated to individual experiences, and unrelated to the threat of drug violence in close proximity to respondent.

\begin{tabular}{|c|c|c|c|c|}
\hline & Model 1 & Model 2 & Model 3 & Model 4 \\
\hline Variables & $\begin{array}{l}\text { Interpersonal } \\
\text { Trust } \\
\text { (Robust } \\
\text { Clustered } \\
\text { Standard } \\
\text { Errors) }\end{array}$ & $\begin{array}{l}\text { Trust in } \\
\text { Judiciary } \\
\text { (Robust } \\
\text { Clustered } \\
\text { Standard } \\
\text { Errors) }\end{array}$ & $\begin{array}{l}\text { Trust in } \\
\text { National } \\
\text { Legislature } \\
\text { (Robust } \\
\text { Clustered } \\
\text { Standard } \\
\text { Errors) }\end{array}$ & $\begin{array}{l}\text { Trust in Local } \\
\text { Government } \\
\text { (Robust } \\
\text { Clustered } \\
\text { Standard Errors) }\end{array}$ \\
\hline \multicolumn{5}{|l|}{ Individual Level } \\
\hline $\begin{array}{l}\text { Was individual a victim } \\
\text { of crime in last } 12 \\
\text { months }\end{array}$ & $\begin{array}{l}1.087 \\
(.191)\end{array}$ & $\begin{array}{l}1.261 \\
(.219)\end{array}$ & $\begin{array}{l}1.102 \\
(.212)\end{array}$ & $\begin{array}{l}1.419 * * \\
(.221)\end{array}$ \\
\hline $\begin{array}{l}\text { Respondent feels unsafe } \\
\text { in neighborhood }(1=\text { very } \\
\text { safe, } 4=\text { very unsafe })\end{array}$ & $\begin{array}{l}.691 * * * * \\
(.056)\end{array}$ & $\begin{array}{l}.946 \\
(081)\end{array}$ & $\begin{array}{l}.857 \\
(.082)\end{array}$ & $\begin{array}{l}.805 * * \\
(.074)\end{array}$ \\
\hline $\begin{array}{l}\text { Respondent feels less } \\
\text { safe in neighborhood }\end{array}$ & $\begin{array}{l}.751 * * \\
(.112)\end{array}$ & $\begin{array}{l}.627 * * * * \\
(.075)\end{array}$ & $\begin{array}{l}.801 \\
(.109)\end{array}$ & $\begin{array}{l}.768 * * \\
(.102)\end{array}$ \\
\hline
\end{tabular}




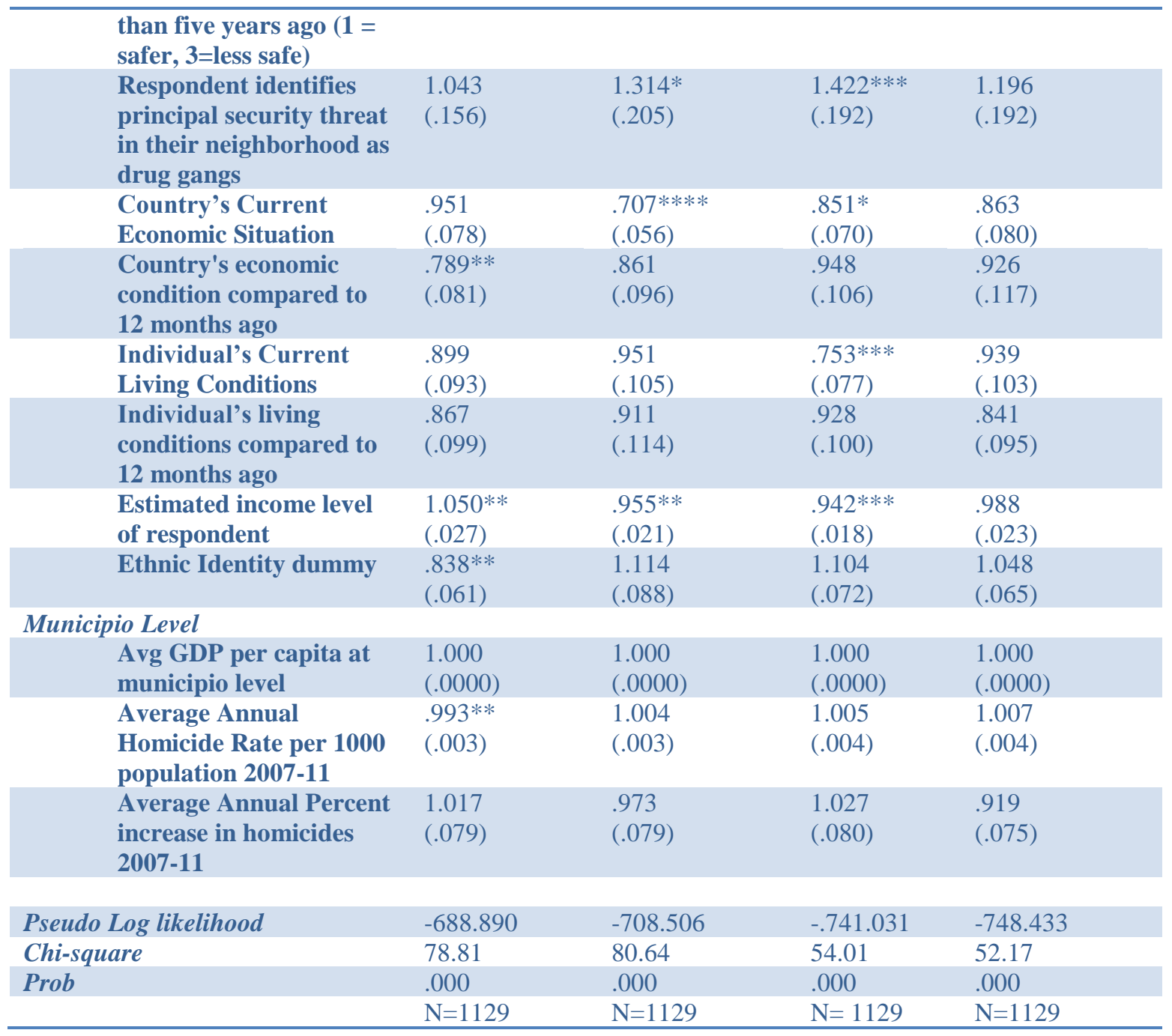

Turning to trust in institutions, it is important to note that we did not include the presidency, because popular judgments about the presidency often conflate assessments of the president as an individual as opposed to the presidency as an institution. Thus, assessments of the presidency are omitted here. However, when examining levels of trust in other governmental institutions, again the results at the individual level do not support hypothesis 1 . Exposure to criminal violence does not reduce trust in political institutions - in fact there is generally a positive relationship between whether the individual had been a victim of criminal activity and their trust in political institutions (particularly local government). However, at the neighborhood 
level, as with social trust, a lower sense of security does lead to less trust in political institutions across all models in Table 2 (although not all relationships are statistically significant). At the municipio level, however neither the level of violence, nor the level of increase in violence (contrary to hypothesis 2 a above) are related to the likelihood that a respondent would express greater or less trust in the judiciary, the national legislature and in local government. These findings are generally in contrast to much of the literature that holds that violence should result in the reduction of institutional trust.

However, as we noted above, there is a potential endogeneity problem when examining the relationship between violence and interpersonal trust (as well as other forms of trust). In other words, although violence may affect trust, the lack of trust, or lower levels of trust, can also lead to higher levels of violence (a point made by many scholars in the literature). To address this possibility, we propose a very simple way to assess the effects of violence on trust. ${ }^{2}$ First, we identify 21 municipios that appeared in the LAPOP data for both 2006 (the year before the dramatic rise in violence brought on by the Calderon administration) and the 2012 wave. Then we divide the sample into two, differentiating between high violence municipios (with homicides of 10 or over per 10000 population) and those with relatively low violence (or less than 10 per 10000 population). Of the 21 municipios, 12 were high violence and 9 were low violence (the list of municipios is reported in table 3). As a baseline analysis we then conducted a simply contingency table analysis and found that in 2006 there were not significant differences between what turned out to be high violence municipios (in 2012) and low violence municipios in terms of trust. The results for social trust are reported in table 4, but similar results hold for the other forms of trust. 


\begin{tabular}{|l|l|l|}
\hline \multicolumn{3}{|c|}{ Table 3: Locations of municipios included that were included in the 2006 and } \\
\hline Region & State & Municipality \\
\hline Northwest & Baja California & Tijuana \\
\hline Southeast & Chiapas & Tuxtla Gutiérrez \\
\hline Northwest & Chihuahua & Chihuahua \\
\hline Center & Distrito Federal & Iztacalco \\
\hline Center & Distrito Federal & Iztapalapa \\
\hline Center & Distrito Federal & Álvaro Obregón \\
\hline West & Guanajuato & Dolores Hidalgo \\
\hline Center & Hidalgo & San Felipe de Orizatlan \\
\hline West & Jalisco & Zapopan \\
\hline Center & México & Cuautitlán Izcalli \\
\hline Center & México & Ecatepec de Morelos \\
\hline Center & México & Nezahualcóyotl \\
\hline Center & México & Tlalnepantla de Baz \\
\hline West & Michoacán & Morelia \\
\hline Northeast & Nuevo León & Monterrey \\
\hline Center & Puebla & Puebla \\
\hline Northwest & Sinaloa & San Luis Rio Colorado \\
\hline Northwest & Sonora & Guaymas \\
\hline Northeast & Tamaulipas & Matamoros \\
\hline Northeast & Tamaulipas & Reynosa \\
\hline Southeast & Veracruz & Papantla \\
\hline
\end{tabular}

\begin{tabular}{|l|l|l|}
\hline \multicolumn{3}{|l|}{$\begin{array}{l}\text { Table 4: Comparing level of social trust, low violence municipalities vs high } \\
\text { violence municipalities, 2006 }\end{array}$} \\
\hline & Low violence (2007-11) & High violence (2007-11) \\
\hline Low trust & $39.36 \%$ & $43.29 \%$ \\
\hline High trust & $60.64 \%$ & $56.71 \%$ \\
\hline
\end{tabular}

\footnotetext{
Chi-square $=1.269$

$\operatorname{Pr}=0.26$

$\mathrm{N}=432$
}

After establishing that there were no apriori differences between the high violence and low violence municipios, we then examined whether individuals in high violence municipios expressed lower levels of social and political trust than individuals in low violence municipios 
after the period of rapid increases in violence from 2007-2011. As indicated by the results in table 5, it appears that the effect of the variable "2006-2012" (which was coded as a dummy) was not particularly related to levels of trust, comparing between individuals in low violence and high violence municipios. In other words, if violence had a negative effect on trust, we would expect a much more pronounced impact in a downward direction on the levels of trust among individuals in municipios with high violence when compared to individuals in municipios with low violence. As indicated in the table this was not the case - that the violent period from 20062011 had no discernable impact on levels of social and political trust. Trust among generally went up across all high violence municipios, quite the contrary to what was hypothesized above.

\begin{tabular}{|c|c|c|c|c|c|c|c|c|}
\hline & \multicolumn{2}{|c|}{ Social Trust } & \multicolumn{2}{|c|}{ Judicial Trust } & \multicolumn{2}{|c|}{ Legislative Trust } & \multicolumn{2}{|c|}{$\begin{array}{l}\text { Local government } \\
\text { trust }\end{array}$} \\
\hline & $\begin{array}{c}\text { Model } \\
5\end{array}$ & $\begin{array}{c}\text { Model } \\
6\end{array}$ & $\begin{array}{c}\text { Model } \\
7\end{array}$ & $\begin{array}{c}\text { Model } \\
8\end{array}$ & $\begin{array}{c}\text { Model } \\
9\end{array}$ & $\begin{array}{c}\text { Model } \\
10\end{array}$ & $\begin{array}{c}\text { Model } \\
11\end{array}$ & $\begin{array}{c}\text { Model } \\
12\end{array}$ \\
\hline Variables & $\begin{array}{l}\text { Low } \\
\text { Violence }\end{array}$ & $\begin{array}{l}\text { High } \\
\text { Violence }\end{array}$ & $\begin{array}{l}\text { Low } \\
\text { Violence }\end{array}$ & $\begin{array}{l}\text { High } \\
\text { Violence }\end{array}$ & $\begin{array}{l}\text { Low } \\
\text { Violence }\end{array}$ & $\begin{array}{l}\text { High } \\
\text { Violence }\end{array}$ & $\begin{array}{l}\text { Low } \\
\text { Violence }\end{array}$ & $\begin{array}{l}\text { High } \\
\text { Violence }\end{array}$ \\
\hline \multicolumn{9}{|l|}{ Individual Level } \\
\hline $\begin{array}{l}\text { Country's Current } \\
\text { Economic Situation }\end{array}$ & $\begin{array}{l}.982 \\
(.118)\end{array}$ & $\begin{array}{l}.824 \\
(.124)\end{array}$ & $\begin{array}{l}.573 * * * * \\
(.071)\end{array}$ & $\begin{array}{l}.586 * * * \\
(.102)\end{array}$ & $\begin{array}{l}.611 * * * * \\
(.076)\end{array}$ & $\begin{array}{l}.739 * * \\
(.114)\end{array}$ & $\begin{array}{l}.609 * * * * \\
(.076)\end{array}$ & $\begin{array}{l}.644^{* * * *} \\
(.105)\end{array}$ \\
\hline $\begin{array}{l}\text { Country's economic } \\
\text { condition compared } \\
\text { to } 12 \text { months ago }\end{array}$ & $\begin{array}{l}.977 \\
(.119)\end{array}$ & $\begin{array}{l}.905 \\
(.133)\end{array}$ & $\begin{array}{l}.969 \\
(.117)\end{array}$ & $\begin{array}{l}1.346 \\
(.023)\end{array}$ & $\begin{array}{l}.992 \\
(.123)\end{array}$ & $\begin{array}{l}1.310 \\
(.225)\end{array}$ & $\begin{array}{l}1.089 \\
(.139)\end{array}$ & $\begin{array}{l}.819 \\
(.141)\end{array}$ \\
\hline $\begin{array}{l}\text { Individual's } \\
\text { Current Living } \\
\text { Conditions }\end{array}$ & $\begin{array}{l}.695^{* * * *} \\
(.101)\end{array}$ & $\begin{array}{l}.956 \\
(.182)\end{array}$ & $\begin{array}{l}.1 .013 \\
(.929)\end{array}$ & $\begin{array}{l}.959 \\
(.182)\end{array}$ & $\begin{array}{l}.995 \\
(.143)\end{array}$ & $\begin{array}{l}1.052 \\
(.198)\end{array}$ & $\begin{array}{l}1.128 \\
(.162)\end{array}$ & $\begin{array}{l}1.386 \\
(.297)\end{array}$ \\
\hline $\begin{array}{l}\text { Individual's living } \\
\text { conditions } \\
\text { compared to } 12 \\
\text { months ago }\end{array}$ & $\begin{array}{l}.918 \\
(.143)\end{array}$ & $\begin{array}{l}.912 \\
(.197)\end{array}$ & $\begin{array}{l}1.195 \\
(.194)\end{array}$ & $\begin{array}{l}.692 * \\
(.155)\end{array}$ & $\begin{array}{l}.816 \\
(.127)\end{array}$ & $\begin{array}{l}.700 * \\
(.151)\end{array}$ & $\begin{array}{l}1.053 \\
(.164)\end{array}$ & $\begin{array}{l}.811 \\
(.181)\end{array}$ \\
\hline $\begin{array}{l}\text { Was individual a } \\
\text { victim of crime in } \\
\text { last } 12 \text { months }\end{array}$ & $\begin{array}{l}1.303 \\
(.258)\end{array}$ & $\begin{array}{l}1.032 \\
(.251)\end{array}$ & $\begin{array}{l}1.032 \\
(.190)\end{array}$ & $\begin{array}{l}2.668 * * * \\
(.919)\end{array}$ & $\begin{array}{l}1.019 \\
(.194)\end{array}$ & $\begin{array}{l}1.410 \\
(.464)\end{array}$ & $\begin{array}{l}.953 \\
(.172)\end{array}$ & $\begin{array}{l}3.332 * * * * \\
(1.197)\end{array}$ \\
\hline $\begin{array}{l}\text { Estimated income } \\
\text { level of respondent }\end{array}$ & $\begin{array}{l}1.004 \\
(.003)\end{array}$ & $\begin{array}{l}1.012^{* *} \\
(.006)\end{array}$ & $\begin{array}{l}1.005^{*} \\
(.003)\end{array}$ & $\begin{array}{l}.994 \\
(.005)\end{array}$ & $\begin{array}{l}1.005 \\
(.003)\end{array}$ & $\begin{array}{l}.998 \\
(.005)\end{array}$ & $\begin{array}{l}1.047 \\
(.058)\end{array}$ & $\begin{array}{l}1.016^{* *} \\
(.007)\end{array}$ \\
\hline $\begin{array}{l}\text { Ethnic Identity } \\
\text { dummy }\end{array}$ & $\begin{array}{l}.983 \\
(.053)\end{array}$ & $\begin{array}{l}.916 \\
(.130)\end{array}$ & $\begin{array}{l}1.085 \\
(.061)\end{array}$ & $\begin{array}{l}1.127 \\
(.157)\end{array}$ & $\begin{array}{l}1.113^{* *} \\
(.063)\end{array}$ & $\begin{array}{l}1.244 \\
(.186)\end{array}$ & $\begin{array}{l}1.047 \\
(.058)\end{array}$ & $\begin{array}{l}1.273 \\
(.224)\end{array}$ \\
\hline \multicolumn{9}{|l|}{ Municipio level } \\
\hline $\begin{array}{l}\text { Avg GDP per capita } \\
\text { at municipio level }\end{array}$ & $\begin{array}{l}1.000 \\
(.000)\end{array}$ & $\begin{array}{l}1.000 \\
(.000)\end{array}$ & $\begin{array}{l}1.000 \\
(.000)\end{array}$ & $\begin{array}{l}1.000 \\
(.000)\end{array}$ & $\begin{array}{l}1.000 \\
(.000)\end{array}$ & $\begin{array}{l}1.000 \\
(.000)\end{array}$ & $\begin{array}{l}1.000 \\
(.000)\end{array}$ & $\begin{array}{l}1.000 \\
(.000)\end{array}$ \\
\hline $\begin{array}{l}\text { Average Annual } \\
\text { Homicide Rate per }\end{array}$ & $\begin{array}{l}1.156 \\
(.097)\end{array}$ & $\begin{array}{l}1.009 \\
(.009)\end{array}$ & $\begin{array}{l}.881 \\
(.085)\end{array}$ & $\begin{array}{l}1.009 \\
(.009)\end{array}$ & $\begin{array}{l}.897 \\
(.091)\end{array}$ & $\begin{array}{l}.994 \\
(.009)\end{array}$ & $\begin{array}{l}.914 \\
(.120)\end{array}$ & $\begin{array}{l}1.021 \\
(.019)\end{array}$ \\
\hline
\end{tabular}




\begin{tabular}{lllllllll}
\hline $\begin{array}{l}\text { 1000 population } \\
\text { 2007-11 }\end{array}$ & & & & & & & & \\
$\begin{array}{l}\text { Average Annual } \\
\text { Percent increase in } \\
\text { homicides 2007-11 }\end{array}$ & .743 & $.721^{*}$ & 1.622 & $.690^{* *}$ & 1.727 & 1.112 & 1.431 & $.435^{*}$ \\
$\mathbf{2 0 0 6}$ vs 2012 & 1.024 & 1.038 & 1.009 & 1.010 & $.921^{* *}$ & 1.020 & .959 & $1.119^{*}$ \\
Log likelihood & $(.033)$ & $(.051)$ & $(.034)$ & $(.051)$ & $(.032)$ & $(.051)$ & $(.033)$ & $(.067)$ \\
Chi-square & -348.097 & -156.117 & -344.329 & -157.047 & -344.854 & -158.170 & -353.979 & -138.563 \\
Prob & 24.67 & 26.62 & 32.55 & 28.76 & 43.02 & 17.29 & 21.53 & 28.85 \\
& .012 & 005 & .000 & .002 & .000 & .01 & .02 & .002 \\
& $\mathrm{~N}=544$ & $\mathrm{~N}=253$ & $\mathrm{~N}=544$ & $\mathrm{~N}=255$ & $\mathrm{~N}=549$ & $\mathrm{~N}=255$ & $\mathrm{~N}=549$ & $\mathrm{~N}=255$ \\
\hline
\end{tabular}

\section{Conclusions}

The results suggest that, contrary to most literature on the topic, the level violence in Mexico does not appear to have a direct effect on levels of social trust and trust in political institutions. Generally, at the individual level, individual experiences with violence and crime had no discernable effect on the level of social trust and in fact had a positive effect on institutional trust (contrary to much of the literature that suggests a direct relationship between individual experience and individual attitudes). However, the effect of violence is largely sociotropic. Indeed, a general sense of insecurity at the neighborhood level is related to reductions in levels of social trust. This would support more neighborhood sociotropic interpretations regarding the effects of violence on attitudes. If people perceive violence to be a great problem, they will have less social and institutional trust regardless, even if they themselves have not experienced violence, nor if there are high levels of violence in the municipality in which they live.

The results suggest some rethinking is needed regarding the effects of violence on social and political trust. First there is little support for the thesis that criminal violence reduces social trust at the individual level. This may question the literature that suggests such a relationship exists, but it may also be the case that the kind of DTO related violence in Mexico is very different from the violence that occurs in civil wars. Indeed, it may be the case that violence is 
largely compartmentalized by individuals to gang violence (or the belief that gang members are killing each other, and that has very little to do with "regular" people). Thus it is not surprising that individual experiences with violent crime and higher levels of municipio levels of violence are unrelated to individual attitudes---the violence around them does not touch the social relationships that individuals have with others, and does not affect how they perceive the performance of political institutions.

However, if people feel generally insecure, then this negatively impacts social and institutional trust. The results would suggest it is not because of experience with violence, nor because of knowledge of actual levels of violence in one's city or community, but the sense of insecurity that leads to less social and institutional trust.

The above findings, however, may also have broader implications. On the one hand, it might suggest that mass violence (including civil wars and civil conflict) does have a negative effect on social and political trust, but not in the direct way that is portrayed in much of the literature. Violence shapes perception, and the sense of insecurity that results (i.e. the sociotropic effect of violence) reduces social and institutional trust, even for people who may live in otherwise secure communities, or who have not experienced violence themselves. However, on the other hand, it may be the case that the type of criminal violence that is rampant in Mexico is fundamentally different than other forms of civil conflict (which would contradict claims that the large-scale violence in Mexico is akin to civil war). Hence, large-scale drug violence may be less likely to directly lead to declines in social and institutional trust, than, for example, civil wars. Violence in Mexico is less likely to directly affect individuals than violence in civil wars, which would suggest that large-scale drug violence should have a very different effect on individual attitudes than civil wars. Whatever the case, much more work needs to be 
done to investigate the relationship between violence and social and institutional trust, because such effects will undoubtedly have important and lasting effects on the development of democracy in Mexico, and elsewhere.

\section{References}

Almond Gabriel and Sidney Verba. 1963. The Civic Culture Princeton: Princeton University Press.

Astorga, Luis. 2005. El siglo de las drogas. Mexico City: Plaza y Janés.

Avantidis, Pschalis, Athina Economou, and Christos Kollias. 2016. “Terrorism's effects on social capital in European countries" Public Choice 169(4): 231-250

Bellows, John, and Edward Miguel. 2006. "'War and Institutions: New Evidence from Sierra Leone." American Economic Association, Papers and Proceedings 96 (2): 394-99.

Bellows, John, and Edward Miguel. 2009. "War and Local Collective action in Sierra Leone.' Journal of Public Economics 93:1144-57.

Benson, Michelle and Thomas Rochon. 2004. "Interpersonal Trust and the Magnitude of Protest: A Micro and Macro Level Approach" Comparative Political Studies 37(4): 435-457.

Bergal, C. 2011. The Mexican Drug War: The Case for a Non-International Armed Conflict Classification. Fordham International Law Journal, 34(4), 1042-1087.

Blanco Luisa R. 2013. “The impact of crime on trust in institutions in Mexico" European Journal of Political Economy 32(1): 38-55

Blattman, Christopher. 2009. "From violence to voting: War and political participation in Uganda", American Political Science Review 103(2), 231-247.

Bohara, Alok, Neil J. Mitchell, and Mani Nepal. 2006. "Opportunity, Democracy, and the Exchange of Political Violence: A Subnational Analysis of Conflict in Nepal" Journal of Conflict Resolution February 50(1): 108-128

Brehm, John and Wendy Rahn. 1997. "Individual-Level Evidence for the Causes and Consequences of Social Capital,” American Journal of Political Science 41 (4): 999-1023.

Calhoun, Lawrence G., and Richard G. Tedeschi. 2006. Handbook of Posttraumatic Growth. Research and Practice. Mahwah, NJ: Lawrence and Erlbaum Associates 
Cassar, A., Grosjean, P. and Whitt, S. 2013., 'Legacies of violence: trust and market development', Journal of Economic Growth 18(3), 285-318.

Chanley, Virginia A., Thomas J. Rudolph and Wendy M. Rahn. 2000. “The Origins and Consequences of Public Trust in Government: A Time Series Analysis." Public Opinion Quarterly 64: 239-256.

Colletta, N. J., and M. L. Cullen (2000) Violent conflict and the transformation of social capital, Washington, D.C: The World Bank.

De Juan, Alexander, and Jan Henryk Pierskalla. 2016. "Civil war violence and political trust: Microlevel evidence from Nepal” Conflict Management and Peace Science 33(1): 67-88

Dinesen C, Ronsbo H, Juárez C, González M, Estrada Méndez MA, and Modvig J. 2013. "Violence and social capital in post-conflict Guatemala". Revue Panamemerica Salud Publica. 43(3):162-168.

Dube Arindrajit, Oeindrila Dube, and Omar García-Ponce. 2012. “Cross-Border Spillover: U.S. Gun Laws and Violence in Mexico” American Political Science Review.

Durlauf, Steven N. (1999) “The Case 'Against' Social Capital,” Focus 20 (3): 1-5.

Easton, David. 1965. A Framework for Political Analysis. Englewood Cliffs, N. J.: Prentice-Hall, Inc.

Escalante, Fernando. 2011. "Homicidios 2008-2009: La muerte tiene permiso." Nexos, January 03.

Esteban ,Joan-Maria and Debraj Ray (1994), "On the Measurement of Polarization," Econometrica 62(4): 819-52.

Foley, Michael and Bob Edwards .1996. "The Paradox of Civil Society,” Journal of Democracy $73: 38-52$

Fukuyama, Francis. 1995. Trust: The Social Virtues and the Creation of Prosperity. New York: Free Press.

Garcia-Ponce Omar and Benjamin Pasquale (2013) "How Political Violence Shapes Trust in the State" unpublished manuscript

Geys, B. and S Qari. 2017. "Will you still trust me tomorrow? The causal effect of terrorism on social trust". Public Choice 173 (3): 289-305.

Gilligan, Michael J., Benjamin J. Pasquale, and Cyrus Samii. 2013. "Civil War and Social Cohesion: Lab-in-the-field Evidence from Nepal. ' American Journal of Political Science 58 (3): 1-16. 
Glaeser, Edward, Bruce Sacerdote, and Jose A. Scheinkman. 1996. "Crime and Social Interactions," Quarterly Journal of Economics 111 (2): 507-48

Glaeser, Edward and Bruce Sacerdote. 1999. "Why Is There More Crime in Cities?” Journal of Political Economy 107(6): S225-S258

Glaeser, Edward L., David I. Laibson, Jose A. Scheinkman, and Christine L. Soutter. 2000.

“'Measuring Trust.' The Quarterly Journal of Economics 111 (3): 811-46.

Grayson, George. 2011. Mexico: Narco-Violence and a Failed State? Transaction Publishers

Hernández, Ernesto. 2011. "Elecciones en estados borderline: el caso de Sinaloa". El Cotidiano 165(1): 31-39.

Hutchison, Marc L., and Kristin Johnson. 2011. Capacity to Trust? Political Capacity, Conflict, and Political Trust in Africa, 2000-2005. Journal of Peace Research. 48(6): 737-752

Hoglund, Kristine. 2008. "Violence in War-to_Democracy Transitions" in Anna K. Jarstad, Timothy D. Sisk editors From War to Democracy New York: Cambridge University Press, pp. 80-97

Inglehart, Ronald F., and Christian Welzel. 2005. Modernization, cultural change, and democracy: the human development sequence. New York: Cambridge University Press.

Ishiyama, John. 2014. “ Civil Wars and Party Systems” Social Science Quarterly 95(2): 425-447.

Kalyvas, Stathis. 2015. "How Civil Wars Help Explain Organized Crime - and How They Do Not" Journal of Conflict Resolution 59(8):1517-1540.

Kijewski, Sara and Markus Freitag. 2016. "Civil War and the Formation of Social Trust in Kosovo: Post traumatic Growth or War-related Distress?” Journal of Conflict Resolution, https://doi.org/10.1177/0022002716666324

Klesner Joseph and Chappell Lawson. 2001. "Adiós to the PRI? Changing Voter Turnout in Mexico's Political Transition," Mexican Studies 17 (1): 20-40

Knack, Stephen and Philip Keefer. 1997. "Does Social Capital Have an Economic Payoff? A Cross-Country Investigation”. Quarterly Journal of Economics. 1124.: 1251-88.

Lederman Daniel, Norman Loayza, and Ana Marı Menendez. 2002. "Violent Crime: Does Social Capital Matter?" Economic Development and Cultural Change, 50(3): 509-539

Mackie, G. 2001. "Patterns of Social Trust in Western Europe and Their Genesis." in Cook, K.S., ed. Trust in Society. New York: Russell Sage. 
Michaud, Katherine. 2011. "Mexico’s Militarized Anti-Drug Policy: Understanding Its Origins Through Examination of Institutional Legacies, Democratization, and Public Opinion"Sanford Journal of Public Policy. 2(1)

Mohlzan, Cory, Octavio Rodriguez Ferreira and David Shirk.2013. Drug Violence in Mexico San Diego: Transborder Institute, Joan Kroc Center for Peace Studies.

Newton, Kenneth and Pippa Norris. 2000. "Confidence in Public Institutions: Faith, Culture, or Performance?" In Susan J. Pharr and Robert D. Putnam eds.., Disaffected Democracies: What's Troubling the Trilateral Countries? Princeton: Princeton University Press, 52-73.

O’Neil, Shannon. 2009 “The Real War in Mexico: How Democracy Can Defeat the Drug Cartels" Foreign Affairs 88 (4): 62-77

Osorio, Javier. 2012. "Democratization and Drug Violence in Mexico." Unpublished Working paper, University of Notre Dame.

Palma, Esperanza. 2010. "México: entre la violencia y la consolidación del sistema de partidos". Revista de Ciencia Política 30(2): 379-396.

Putnam, Robert. 1993. Making Democracy Work: Civic Traditions in Modern Italy. Princeton, NJ: Princeton University Press.

Putnam, Robert. 1995. “Bowling Alone: America’s Declining Social Capital.” Journal of Democracy. 5: 65-78.

Putnam, Robert. 2000. Bowling Alone: The Collapse and Revival of American Community. New York, Simon and Schuster, 2000

Putnam, Robert. 2007. "E Pluribus Unum: Diversity and Community in the Twenty-First Century. The Johan Skytte Prize Lecture.” Scandinavian Political Studies 30:137-174

Ley, Sandra. 2017. “To Vote or Not to Vote: How Criminal Violence Shapes Electoral Participation" Journal of Conflict Resolution: online first

Ley, Sandra. 2015. Violence and Citizen Participation in Mexico: From the Polls to the Streets Briefing Paper Washington DC: Woodrow Wilson Center for International Scholars accessed October 15, 2015 at https://www.wilsoncenter.org/sites/default/files/Violence\%20and\%20Citizen\%20Partici pation $\% 20$ in $\% 20$ Mexico 0.pdf.

Rios Viridiana Ríos and David A. Shirk. 2010 "Drug violence in Mexico: data and analysis from 2001-2009” Trends in Organized Crime13,(3):167-174

Robison, Lindon and Marcelo E. Siles .1999. "Social Capital and Household Income Distributions in the United States: 1980, 1990," Journal of Socio-Economics 28,(1): 34-93 
Rodríguez, Victoria and Peter Ward. 1994. "Disentangling the PRI from the Government in Mexico," Mexican Studies 10(1): 166-180

Rubio Mauricio.1997. "Perverse Social Capital-Some Evidence from Colombia,” Journal of Economic Issues 31: 805-816.

Schedler, Andreas. 2013. ' Mexico's Civil War Democracy.' Paper prepared for presentation at the 109th Annual Meeting of the American Political Science Association (APSA), Chicago, August 29-September 1.

Schedler, Andreas. 2015. "The Criminal Subversion of Mexican Democracy" Journal of Democracy 25(1) 5-18.

Tedeschi, Richard G., and Lawrence G. Calhoun. 1996. “"The Post-traumatic Growth Inventory: Measuring the Positive Legacy of Trauma.' Journal of Traumatic Stress 9:455-71.

Váldez, Andrés and Paniagua, Abraham. 2011. "Criminalidad, inseguridad pública y comportamiento de los electors: un análisis del proceso electoral estatal 2010 en Ciudad Juárez, Chihuahua". Estudios Fronterizos 12(23): 49-78.

Voors, M. J. and Bulte, E. H. 2014. "Conflict and the evolution of institutions at the local level in Burundi”, Journal of Peace Research 51(4), 455-469.

Notes

1 Two important exceptions are the recent work of Blanco (2013) Schedler (2014) and Rey (2015.

2 Unfortunately, the variables related to neighborhood effects are excluded from the analysis, because these questions were not included in the LAPOP 2006 wave. 